\title{
Paradigma Nusantara: Decolonizing Science Agenda
}

\author{
Aji Dedi Mulawarman \\ Universitas Brawijaya, Jl. MT. Haryono 165, Malang 65145, East Java, Indonesia \\ ajidedim@ub.ac.id
}

ARTICLE INFO

Article history

Received 9 August 2021

Revised 15 August 2021

Accepted 20 August 2021

Keywords

Hikmah;

Decolonization of science;

Kaidah;

Paradigma Nusantara.

\begin{abstract}
This research aims to propose Paradigma Nusantara as a means to redirect science to the roots of cultural and religious values that become the human characters of Nusantara. By using Hikmah philosophy, this paradigm was built with principal tenets. Modern paradigms are built with philosophical assumptions (epistemology, ontology, axiology/human nature), which reflect anthropocentric interests. Paradigma Nusantara, on the other hand, is built with four substantive tenets (kaidah substantif), namely Nusantara being, integral view of reality, religiousity and culture, and the objective of Nusantara knowledge. This paradigm, if applied into practice will be able to decolonize science, including accounting, that in the present time is still dense with Western and secular values, and will bring about creation of science that is in accordance with religions and local wisdom (culture).
\end{abstract}

This is an open access article under the CC-BY-SA license

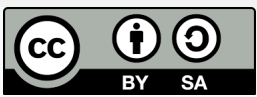

\section{Introduction}

ana kidung rumekso ing wengi/ teguh hayu luputa ing lara/luputa bilahi kabeh/ jin setan datan purun/ paneluhan tan ana wani/ niwah panggawe ala/gunaning wong luput/geni atemahan tirta/ maling adoh tan ana ngarah ing mami/guna duduk pan sirno// Rumekso Ing Wengi - Sunan Kalijogo

My encounter with the Nusantara view started in 2000, when I began interacting with the world of education. Various Nusantara thoughts are still prevalent in traditional games, children's learning models at school, and in curriculum that brings together national education system, which has a pro-internationalization tendency and is very close to Western thought, with traditions that are still alive around Singosari, Malang Regency. Singosari still maintains traditional values because this place was before the Singosari Kingdom (1222-1292), which became the initial milestone of the Nusantara's civilization which was echoed by Majapahit and lasted hundreds of years (1293-1520). Singosari is also the place where the Islamic tradition with the spirit of Nusantara still exists to this day, with dozens of Islamic boarding schools scattered in this area. The first Islamic boarding school in Singosari, Bungkuk based on historical records, was founded between 1830-1850 by one of Prince Diponegoro's army who fled after the Java War. Even wider when photographed from the scale of the Greater Malang region (Malang Regency, Malang City, and Batu City), local Javanese traditions/mysticism/spirituality are still strong with Islamic 
religious values. Similar cases can also be found in many areas, such as Madura, Sulawesi, Lombok, Sumbawa, Sumatra, and others. The presence of religious values that are the center of culture can be different in the space and time of the Nusantara, for example, Toraja, which has a strong Christian or Bali with its Hindu nuance.

It is natural that Nusantara discourse will always appear religiously-culturally and formally among people in various parts of Indonesia. The Nusantara view became more interesting both existentially and substantively when I began to enter the academic space, by attending master's and doctoral lectures. In these areas, the discourse was growing and expanding through meetings with intellectuals, culturalists, and cultural arts practitioners around Java. Interest in the height and nobility of the knowledge and culture of the Nusantara further adds to the belief that the culture of this Nusantara archipelago must have its own world view. Library shelves and laptop files, which were once dominated by Western thought, have since been replaced by books and articles with Indonesian nuances. My Nusantara view was also strengthened after I enjoyed more traditions that are still physically present to these days, such as slametan [1], art performances, visits to historical sites, both in Java and Outside Java.

It is time for the Paradigma Nusantara in the realm of science to be developed as the basis for building civilization. Paradigma Nusantara is actually a further elaboration of the results of my thoughts in recent years. Construction is very important, because research and evidence in the form of academic research such as minor theses, theses, and dissertations, as well as research articles regarding the expression of the embeddedness of locality and religiosity in community practices in Indonesia are indeed real, diverse, and has distinctive uniqueness, although it has not been structured into a firm philosophical backing of the Nusantara values.

One of the proofs of firm philosophical use was when I employed structuralism-based philosophy of technology thinking by Armahedi Mahzar in designing the Sharia Added Value Concept and Report [2] to Sharia Financial Reports [3]. In the process of conducting the research, I became acquainted with the thoughts of HOS Tjokrominoto, KH. Hasyim Asy'ari, and KH. Ahmad Dahlan. The thoughts of these three prominent figures further emphasize that Indonesia has a high value and spirit of partisanship that is timeless, in contrast to logics such as Descartes, Comte, Max Weber, Karl Marx, Husserl, Foucault, and others who are widely used as references by the Modern Paradigm.

Paradigmatic construction is carried out to strengthen the essence of science in a rigid and well-established manner based on the original Nusantara values. This entails a process to emphasize the thinking and scientific structure typical of the Nusantara as the center, as well as the main paradigmatic reference and with that, existing studies are no longer trapped in the possibility of subordination or even become a form of neo-colonization of the Modern science paradigm and its derivatives in order to prove that praxis and science do exist in the space and time of this land.

Paradigma Nusantara for accounting knowledge is a further attempt to elaborate the results of my thoughts in the last few years. The importance of Paradigma Nusantara has often been mentioned in various forums. Written ideas have been established in: the discourse of constructive accounting methodology to grounding religiosity by Ari Kamayanti[4]; one of the chapters on writing scientific articles writen by editors in 
ALJEBI [5]; the preface to Novrida Qudsi Lutfillah's book about Gayatri as the accountant of Majapahit [6]; and my book about agricultural accounting as a prophetic legacy [7]. Science construction, including accounting, is very important because research and evidence in the form of academic research such as minor theses, theses, and dissertations, as well as research articles regarding the expression of the embeddedness of locality and religiosity in the practices of society in Indonesia are indeed real and very diverse, and has a distinctive uniqueness, although it has not been structured from a firm philosophical backing of the Nusantara or the South Eastern Asian archipelago. One of the proofs is the use of the structuralism-based philosophy of technology thoughts by Armahedi Mahzar in designing the sharia added value concept and report [2] to sharia financial reports [8]. It was from this research that I became acquainted with the thoughts of HOS Tjokrominoto, KH. Hasyim Asy'ari, and KH. Ahmad Dahlan. The thoughts of these three prominent figures further emphasize that the Indonesian has a high value and spirit of partisanship that is timeless, in contrast to logics such as Descartes, Comte, Max Weber, Karl Marx, Husserl, Foucault, and others who are widely used as references by the modern paradigm.

Paradigmatic construction is carried out to strengthen the essence of science of accounting in a rigid and well-established manner based on the original Nusantara values. It is imperative to emphasize the unique thinking and scientific structure of the Nusantara as the center as well as the main paradigmatic reference, and with that, existing studies will no longer be trapped in the possibility of subordination or even become a form of neocolonization of the modern science paradigm and its derivatives in order to prove that praxis (and science) of accounting indeed exists in the space and time of this nation.

The Nusantara-based accounting discourse is indeed a result of an open-mindedness in looking at accounting that is not seen from a single paradigm since the late 1990s and early 2000s, along with the emergence of the Multiparadigm Accounting jargon in the Accounting Department, Faculty of Economics and Business, Universitas Brawijaya. In those years the world view of accounting was still dominated by the positivism paradigm which was reflected in his research, especially the issue of market based accounting research, behavioral accounting, positive accounting theory, and the transition to the dominance of the US-GAAP (United States - Generally Accepted Accounting Principles) accounting regulation regime, and from FASB (Financial Accounting Standards Board) to IFRS (International Financial Reporting Standards) led by IASB (International Accounting Standard Boards). The multi-paradigm accounting approach initially used the modern fourparadigm approach. In addition to the Positive Paradigm, accounting can be seen from the depth of its subjective meaning (Interpretive Paradigm); or that accounting must be able to escape from domination and colonialism, both substantively and practically (Critical Paradigm); and even free from the shackles of Modernity and the dogmatism of the everpresent Accounting Logos (Posmodern Paradigm). Further, came the perspective of accounting according to their respective paradigms such as Sharia Accounting [9], Javanese (indegenous) approach to understand accounting practices [10], accounting and corporate culture in an ethnographic perspective [11], Foucauldian accounting history [12], and others. Soon, more multi-paradigm accounting researches emerged until the present days. The dominant journal that accommodates multiparadigmatic ideas and research is the Multiparadigm Accounting Journal. Both the Western-centric approach, synthesis and 
moving to the Nusantara approach can be seen from the articles that have appeared in this journal since 2010 (check out http://jamal.ub.ac.id).

The multi-paradigm approach to accounting is increasingly blooming accounting research from many perspectives that have not previously seen in Indonesia before. The single and dominant perspective of the positivism paradigm is then accompanied by interpretive, critical and postmodern approaches, starting from the values embedded in them to methodological creativity and research methods that have an impact on the research results. An important note that must be made is that the multi-paradigm accounting approach is relatively portraying the reality of Indonesian accounting based on research which sprung from a Western methodological derivative. The use of such methodologies is academically justified, but possesses a Western-centric bias and is close to neo-colonial or post-colonial ideas such as orientalism, epistemic violence or ideological hegemony, or scientific ignorance. Orientalism was first published in 1978 [13]. Other reference to orientalism is the work of Hassan Hanafi's Muqaddimah fi 'ilm al-istighrab (introduction to occidentalism) that was published in 1991 in Cairo, Madbuli [14]. Epistemic violence was first coined by Gayatri Chakravorty Spivak in her article "Can the Subaltern Speak?", which was then revised to a revised version as a book chapter in a book entitled "Can the Subaltern Speak?: Reflections on the History of an Idea" [15]. The term ideological hegemony was used by Ashis Nandy entitled Development and Violence for UNESCO 1994 peace program. Scientific ignorance for Hidayat Nataatmadja is a critic towards the domination of rationality which simultaneously accelerates evil and gives birth to the new era of modern ignorance, that refers to Javanese tradition as the era of Kalabendu (a Jayabaya prophecy) [16]. Accounting research as one part of the construction of neo-colonialism inevitably becomes the center of neo-colonialism itself.

In the late 2000s and early 2010s, a paradigm shift has begun to emerge and is converging on a new research paradigm, such as the spiritual, religious and Nusantara paradigms. During the last 10 years, the development of research and methodological discourse leads to a firm positioning of the paradigm which affirms Nusantara's identity (illustrated in Figure 1). Rejections and arguments about the importance of grounding the archipelago's identity as the center of a worldview spread into an increasingly unstoppable necessity and desire. Epistemic and radical (philosophical) ideas emerged to cross into wisdom spaces where a more noble perspective of the relation between religiosity and culture is formed.

Indigenization and profession of science inevitably become a new discourse space, creation and approach to reality according to the character of culture and religion in all scientific fields, especially the social sciences including accounting. However, we can not simply look at the (history) of accounting as a normative, conceptual, or empirical fact. It is presented in accounting theory, that accounting started from the renaissance period, through its main character, Luca Pacioli. The argument that accounting has historically existed before Pacioli has been widely written, though itswas not even told in linear pattern, is still trapped in the historical sequence according to the West. Accounting, normally as both a science and a practice, has been around for a long time and at a random demographic ranges to form its unique network. One important thing is that when accounting emerged from the very beginning, it was indeed embedded in sacredness, not 
secular or even profane. If accounting is seen in the historical context of a very broad spectrum, it is very possible that accounting has already existed for a long time in this country, the Nusantara.

\section{Figure 1. Paradigmatic evolution of accounting science in Indonesia}

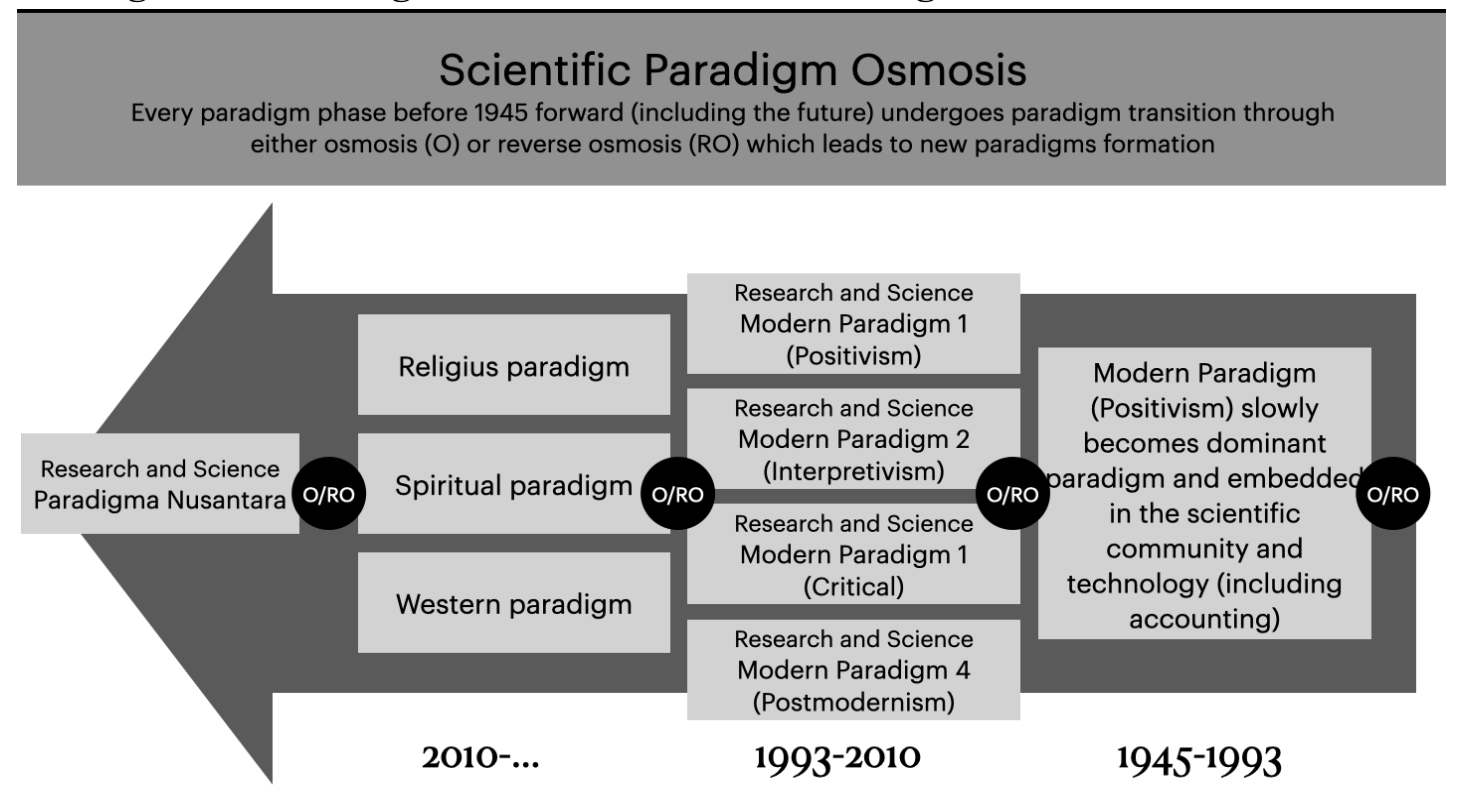

The legitimacy of the Nusantara science (including accounting) thus becomes real, because it is impossible for a great civilization, such as Majapahit or Sriwijaya to exist without an underlying science. How could the magnificent Borobodur stretch out to be one of the wonders of the world built without an established science and technology of that time? It is not enough to think that this nation only has indigenous knowledge but has a maritime culture and the most advanced ships in the Silk Road era, even more sophisticated than those made by Chinese, Greek, Roman, and Indian civilizations, for example [6].

Such view of the world, which is the power that forms the basis of Nusantara philosophy (of science), is clearly different to the modern worldview itself. The main values that underlie how the view of the world from humans (and society), for example about the fact that the universe lives without pause, and the human mind about the inseparable unity between the world of "heaven" and "earth", where the existence of God is always present at all points of life, still present in the space and time of our unique, distinctive and clear Nusantara. The view of the world from the people of the Nusantara in which is lived in that space and time, not only has a diametrical world view, but is even very different to the modern world view.

Another problem is the difficulty for researchers, both students and academics, to get out of the logic and flow of research that has been present before them. Often they are trapped (both consciously and unconsciously) on the dominant modern paradigm, which tends to lead to findings based on basic assumptions of material reality, quantitative/mathematical, or measurable-objective-empirical "concrete" reality, all of which are led to the big assumptions of logical rationality. Modern scientific basic 
assumptions like that occur because of the philosophical prison of science that puts forward a trilogy of ontology, epistemological and axiological steps. Even if there is a development of philosophy of science mapping direction, to emphasize the difference between natural and social sciences, a new patch called human nature appears, which translates the world in terms of the nature of humanity and its society sociology. Scientific misleading to understand the reality of the Nusantara using the modern paradigm has indeed become an unconscious awareness that cause many academics to approach the form of their findings and constructions in the Western's eyes (see Figure 2).

The question is then, how could we escape from the prison snares of the modern paradigm and create a paradigm that is truly Nusantara? This article will explain at length each aspect of Paradigma Nusantara and with that we can find some important keywords how to construct the Paradigma Nusantara for accounting science that really comes from the true nature of the Nusantara's thought.

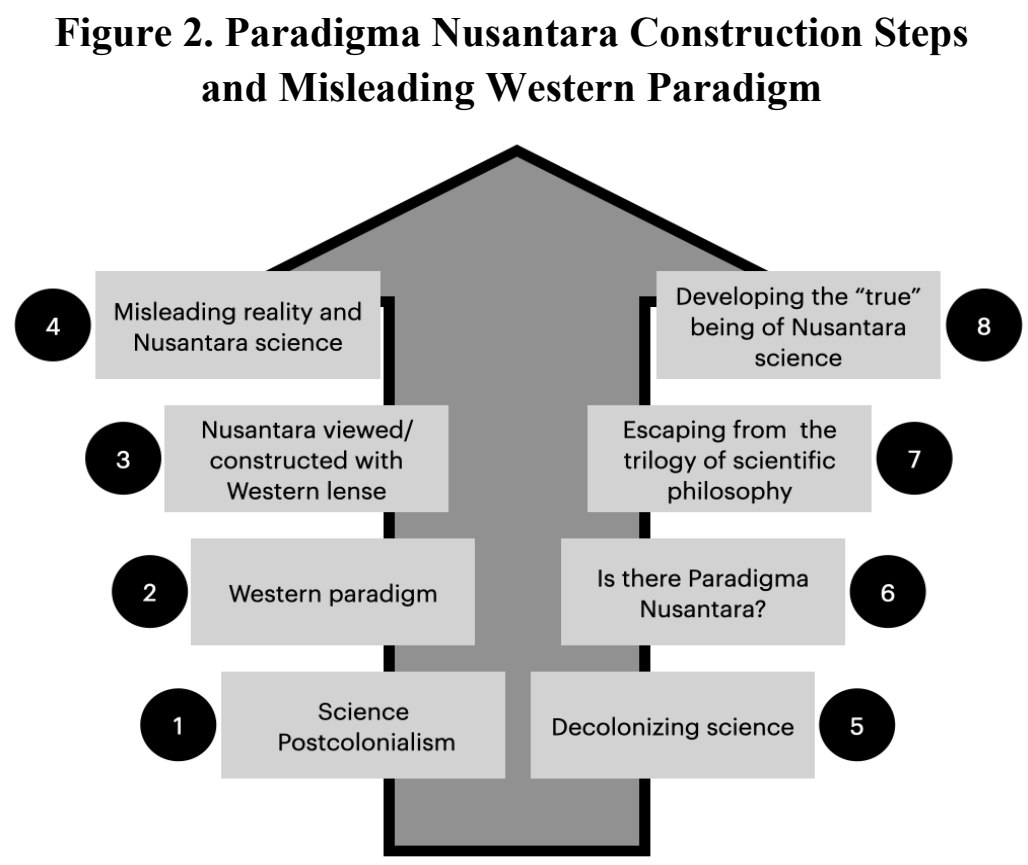

\section{Method}

Paradigma Nusantara will be constructed using a philosophy of wisdom (hikmah) approach. The philosophy of wisdom sees reality differently from the perspective of modern philosophy which approaches reality and knowledge only with the power of rational reason. Hikmah, based on the interpretation of KH. Bisri Mustofa in the book of Tafsir Al-Ibriz li Ma'rifati Tafsir Al-Qur'an Al-Aziz, is a knowledge that Allah presents to every chosen human being who has a high degree of humanity as he/she always understands how reality is the unity of his/her remembrance of God (zikir) and his/her thought as the characteristic of a knowledgeable human (ulil albab).

"Allah Ta'ala maringaken ilmu Kang manfaat marang wong kang dikersaake. Sopo bae kang diparingi ilmu kang manfaat mengko temen wong wawu keparingan 
kebagusan kang agung, nanging ora podo eling kejobo wong kang duwe angenangen (tafakkur)."

Wisdom can be achieved through the unity of rationality as well as spirituality, so that in understanding the world and reality as something sacred or divine, it must have the connectivity of everything in space and time without pause, until it reaches The Light. The Light is a guidance for whomever God wills in the form of wisdom for knowledgeable humans (ulil albab) which is explained by Al Ghazali with his words: "Bi'anal ilmanurun (Knowledge is Light)"; and it is for those who get The Light who will be able to exist eternally across time and space in Myskatul Anwar with the saints and the angels. This is revealed by the Qur'an Surah Al Baqarah (2) verse 269: "God (Allah) gives wisdom to whomever God wills. Whoever is given wisdom, indeed he/she has been given much good. And no one can take lessons except people with understanding (Ulul Albab)."

The praxis of the philosophy of wisdom can be seen from one of the main figures in Indonesia, namely HOS Tjokroaminoto. Intellectual traces in the form of books, articles, and newspaper writings, which have the power to construct how this country can achieve independence. HOS Tjokroaminoto uses the Dutch term, zelfbestuur, which means selfgovernment, with the sanctity of the nature of Islam as the key word for liberation (he uses the Javanese term, Menembah Gusti, as a way of moving oneself and the society/ummah while still prioritizing submission to Allah without pause). The choice of these three keywords "zelfbestuur, menembah, and Gusti" shows that he has the intelligence of religiosity and Nusantara culture; intelligence to carry out relations of modernity, religiosity and local traditions across time and space that have substantive humanitarian goals without leaving their human identity. Substantive expression of the sacred duty of humanity who has complete intelligence (he names this as Insan Kamil) with the height of holiness and history in his real defense in the world as a great hero or what he calls as the Javanese Prawireng Djoerit. Accounting construction has already been proposed in conceptual article entitled "Akuntansi Tjokroan Kritis ala HOS Tjokroaminoto" [17] as well as in the key concepts of religiosity and culture in HOS Tjokroaminoto's biography [18].

The idea of Paradigma Nusantara with the value of intelligence, religiosity and culture of the Nusantara was also evident in Hidayat Nataatmadja's mind, which later became the basis for constructing Accounting education. Likewise, the idea of Nusantara has sprung in the thoughts of Sudjatmoko, RMP Sosrokartono as well as cross-age figures who became references to the power of cultural intelligence, such as Shaykh Jumadil Kubro, Shaykh Syamsuddin al-Wasil, Wali Songo, Prince Diponegoro, Sultan-Sultan of the Archipelago, Pak Muh (KH. Muhammad Zuhri), Agus Sunyoto, Emha Ainun Nadjib, Gus Dur (KH. Abdurrahman Wahid), M. Amien Rais, Soekarno, Kuntowijoyo, Mulyadhi Kartanegara, Mubyarto, Said Tuhuleley, Damardjati Supadjar, and many others. On the sidelines of the struggle for thinking based on the philosophy of wisdom, the idea of Paradigma Nusantara surfaced in 2017 as an important keyword for the development of accounting science. 


\section{Results and Discussions}

\subsection{Fundamental mistakes in accounting philosophical assumptions and their impacts}

The paradigmatic characteristic of science in the Nusantara is different from what is commonly understood as a scientific paradigm so far. The Nusantara paradigm is not tied to the philosophical building of science based on: "ontological, epistemological, human nature (social science) or axiological (natural science)" assumptions. The derivation from methodological to methodical praxis is based on three main reasons. First, because philosophical assumptions about science are usually trapped in modern philosophy of science, which later will easily reject assumptions that are contrary to the rules of science itself because it has been constructed by the nature of thinking in which the philosophical assumptions of science are developed. Second, the second trap is the philosophical assumption of modern science because it always lies in the diametrical separation (opposite) of natural science and social science. Natural science has its own philosophical assumptions, and so does social science. Even the most diametrically stated that a clump of science is considered "scientific knowledge" which must be in the building block of knowledge, with standards for science that must be objective, measurable, and material. Third, the view that social science is different from natural science is because of two important things, namely the cross-cutting of social structures and scientific structures which then form the scientific paradigm of differences in ontology, epistemology, human nature and strict methodology, all framed in the logic of Western/modern centric thinking. Until then, there was a paradigmatic rejection, for example, that the assumptions put forward by Burrell and Morgan [19] were imprisoned by modernity, which triggers postmodern paradigm, that leads to the evolution of spiritual paradigm and so on." Burrell and Morgan's model divides the paradigm into functionalist, interpretive, radical humanist and structuralist paradigms. Chua [20] with various arguments including her criticism of Burrell and Morgan then divides the paradigm into three perspectives, consisting of positive, interpretive and critical paradigms. Another approach can be seen from the paradigm division according to Muhadjir, for example, namely positivist, postpositivist and postmodernism. Many more divisions of scientific paradigms that follow the line of Modern philosophy of science [21].

The important work of Descartes lies in the belief that rationality is the key word of reality, including the proof of the existence of God. If God's existence cannot rationally be proven, then God must be denied. Sociologically and culturally, the post-renaissance European world is indeed a place where scientific activity becomes secular, which was coined by Max Weber as a disenchanted, mechanistic and positivistic world, while the spiritual one is considered to be outside the activities of science and its results (technology). Natural law is deemed not important to be connected with God's law. Religious dogma, intuition and contemplation are obstacles to progress and truth in the name of science. The method of discovering science must be sought using a verification (principle of truth) and falsification process empirically, through the five senses. Culture that has an intertwining relationship with religion can be considered scientific as long as it is justified by the philosophical assumptions of science that are rational, objective and universal. Although an understanding of culture and religion is important by carrying out a 
complete subjective meaning of reality, all of them remain in the corridor of the important goals of science that must be present; namely reality that is characterized with causal relationship and with that other assumptions that need to be present in the process of cultural and scientific science. Religious reality must be free from any myths, mystical aspects, and superstitions. The framework of free work values in the study of the social sciences, including aspects of religion and culture, thus becomes important.

Logic and rationality are important loop holes for Modern/Western humans in realizing their freedom from anyone, including God and all Godly derivatives such as sacred teachings. It is then understandable why thousands of churches are closed in many countries in Europe and Australia, for example, and they are turned into discotheques, post offices, malls, and many others, including mosques. Even in Canada approximately 9000 churches will be torn down in the next few years. On the other hand, on the basis of human freedom and rationality, existing deviant behavior is contextual and empirical in this world, LGBT for example, is a reality that no longer matters at the level of truth or sin. We hence witness inconsistency and paradox of truth.

An example of the paradox of the LGBT and Christian faith is a landmark event on June 21-24, 2021 that the United States Association of Catholic Priests (AUSCP) convenes at its annual meeting in Minneapolis, Minnesota. Three Catholic bishops (John Wester of Santa Fe New Mexico, Richard Pates of Crookston Minnesota, and William Wack of Pensacola Florida) made a controversial agreement to support homosexuality in priesthood and parish life. Even one of the AUSCP vendors, namely New Ways Ministry, an organization condemned by the United States Conference of Catholic Bishops (USCCB) and the Vatican, made a special sticker on the table where they sat, saying "Catholics for Marriage Equality. GOD IS LOVE."

The impact is broad, one of which is in the realm of accounting practice, such as the world-level Public Accounting Firm (KAP) known as the Big Four. One of the global KAPs, Ernst and Young (EY) was named one of the eight Star Performers by Stonewall (https://www.stonewall.org.uk), a lesbian, gay and bisexual rights charity, for providing equality in the world, that provides world of work to lesbian, gay and bisexual employees. The eight organizations selected as The Star Performers according to Stonewall (EY, Accenture, Barclays, Gento, Home Office, Goldman Sachs, IBM, and Simmons \& Simmons) are ranked in the top 10 gay-friendly workplaces based on Stonewall's Equality Index which is released annually. EY specifically pledged to strengthen its commitment to LGBT equality by increasing the visibility and outreach of its LGBT network to regional offices in the UK and Ireland, while IBM will raise awareness of LGBT equality in offices around the world through a global mentoring program. In addition to the company, OUTstanding in Business was also named a top 100 LGBT leader, including four consultants from EY, one of whom was Beth A. Brooke-Marciniak [22]. EY's expression of seriousness can be seen on EY's official website which also informs Beth's commitment to advancing LGBT+ inclusion in the workplace.

PricewaterhouseCoopers (PwC) is not left behind. PwC's extraordinary pro-LGBT+ commitment can be seen from their seriousness in: (1) creating an inclusive workplace including lesbian, gay, bisexual and transgender (LGBT+) within the company; (2) sponsoring Pride Parades around the world; (3) add to the PwC Global Code of Conduct; 
(4) to issue a statement regarding Global Human Rights pro LGBT+. PwC's alignment is also shown by the firm statement of PwC Global Chairman, Bob Moritz on the PwC official website: "Leaders need to be active advocates and allies for LGBT+ equality and inclusion. They can't hide from or ignore these issues - we must be loud in our support for LGBT+ colleagues.” Andy Woodfield, PwC Partner, Head of International Development Consulting as Senior Champion of the Year seriously promotes and develops PwC's business network for "Gay, Lesbian and Everyone (GLEE@PwC)" [23].

In the field of research, the development of accounting and LGBT research has even led to the derivation of Cartesian rationality, through one of the important keywords that transactions must be in accordance with the main concept of income, namely profit. For the Big Four in particular, LGBT, indeed is a reality that exists and has a logical rationality. This rationality must represent the materiality of profits in the form of economic goods. Research by Edgley, Sharma and Anderson-Gough [24] shows that diversity including LGBT as a central issue of the "Big Four" plays an important role in social construction through professional identity. Adopting an institutional logic approach with regard to issues of the world of work, professional accountants and public accounting firms, their research explores the interactions that frame public messages about diversity, equality and inclusiveness that have been institutionalized in the four Global Public Accountants, namely EY, PwC, Deloitte, and KPMG through social media. Research results show the Big Four in positioning diversity, including LGBT as an economic good and aspects of professional excellence that are commercially relevant.

\subsection{Questioning the essence of assumptions and the trilogy of philosophy of science}

The domination of the Cartesian-style scientific rationality can finally push anything to be legitimized, including the paradox of God, religion, faith, and LGBT in general, even specifically in accounting practice. The rationality that Descartes builds is indeed strongly influenced by the environment in which he lives, even though his own view (for me) is less pleasant (if not called racist) when making an equation between the East which prioritizes a non-rational approach (comparing the great Chinese civilization with Cannibals). compared to the very rational West (comparing France and Germany). Descartes' rationality as an expression of European culture must be very subjective. Moreover, Descartes himself emphasized that in fact the findings on rationality and objectivity were obtained from an intuitive process during Descartes's time in joining the military service. A wiser view from Richard E. Nisbet who understands that the difference in rationality is not only about logical praxis, because both East and West have been established for thousands of years, making them different in understanding reality and rationality. Both West and East are homeostatic systems that have implications for understanding the nature of thoughts, beliefs, and appropriate strategies for understanding differences [25].

The "somewhat racist" Cartesian-based general, objective and autonomous characteristics of knowledge, that was criticized and proven as false by Nisbet, later became the dominant current of philosophy of science following an empirical cycle; everything must be done methodically, systematically, logically and in a very detailed process. The research method is a technical means related to the "conduct of research" i.e. how research is carried out systematically based on specified procedures. In essence, 
knowledge about the nature of science internally needs to be studied ontologically (what), epistemologically (how), and axiologically (for what), as well as the means used such as language, logic, mathematics, and statistics. Suriasumantri describes it in the form of a chart of the components of Scientific Thinking Activities. The chart is one of the decisions of the National Science Congress (KIPNAS) III LIPI in Jakarta, 15-19 December 1981 (see Figure 3).

\section{Figure 3. Components of Scientific Thinking Activities}

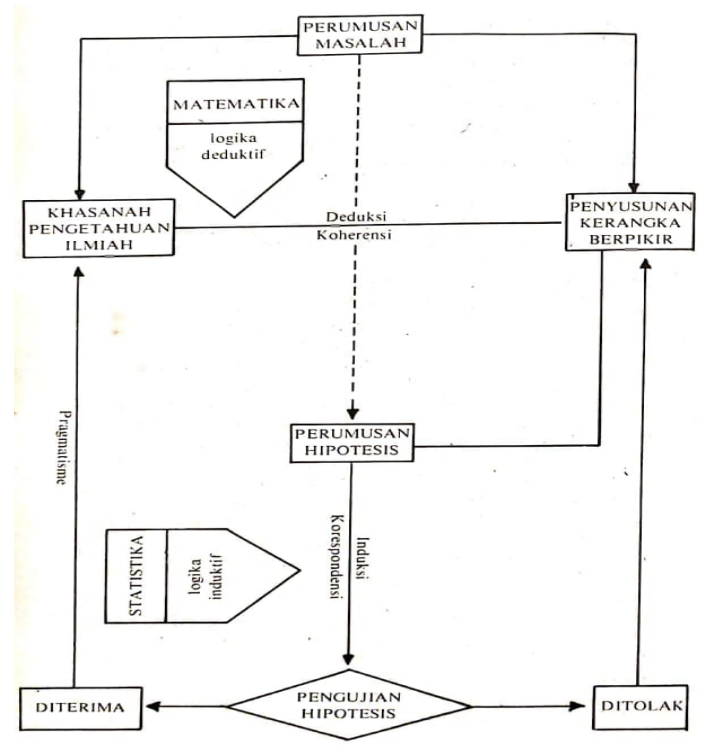

A more technical understanding is translated into, for example, the realm of business, accounting and management which emphasizes that accounting, management and business science is a knowledge that must be approached rationally and tested through a combination of approaches, namely rationalism and empiricism [26]; in whatever paradigm emerges. Quantitative and qualitative paradigms are only distinguished in deductive aspects for quantitative research, while inductive aspects for qualitative research, but in general have stages of the research process with the following requirements: systematic, scientific, representative evidence, logical and unbiased (see Figure 4).

It is interesting that the philosophy of science which has a cyclical way of working based on three foundations (ontology-epistemology-axiology) according to Adisusilo is part of the history of the struggle of Modern/Western thought with the central theme of how to position human nature which has "three interests" over science, namely technical, pragmatic, and emancipatory. Thus, the assumptions built in science that emphasize the necessity of universality, objectiveness, autonomy, which are actually bridged through the ontology-epistemology-axiology trilogy are actually full of contradictions in their own philosophical thinking, because of the trilogy of interests, which must be technical, pragmatic and emancipatory can be summarized in one theme i.e. the importance of the continuity of human existence. Science is thus only concerned with the interests of human 
existence. If science is taken beyond such conformity, for example inserting it with religions and politics, science will be considered unscientific.

\section{Figure 4. Illustration of Research Outline}

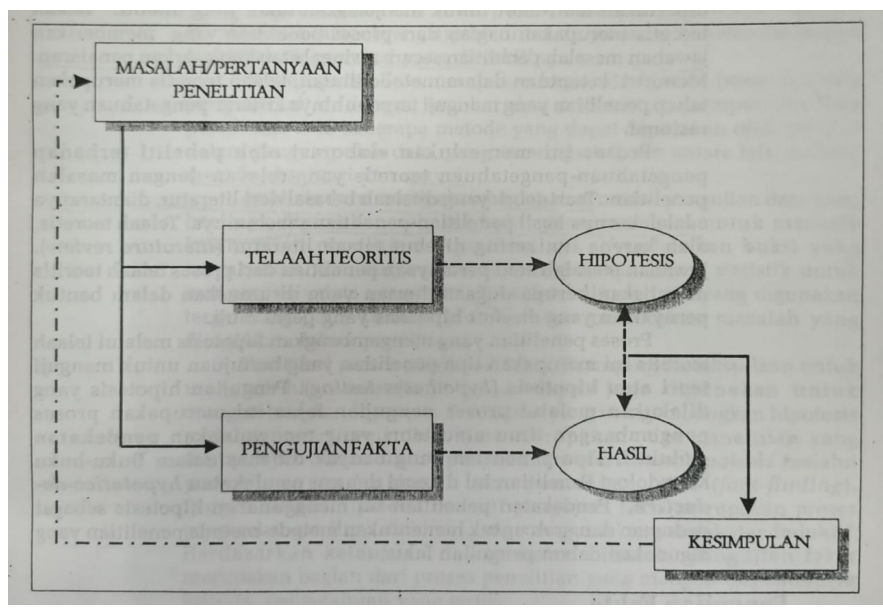

When investigated further, the three ontology-epistemology-axiology trilogy has a rational and empirical basis. The ontology of science limits itself to events that are rational and empirical in nature. Rationalism is knowledge that is believed to be based on reason, as the early ideas of modern philosophy started with Rene Descartes. This Descartes-style rationalism marked the fall of Aristotle's five-sense-based knowledge. In addition to rationalism, modern science also synergizes with the views of Empiricism in the style of Thomas Hobbes, John Locke and David Hume. Because the ontological nature of science is in the empirical reality and rationality of humanity, the epistemology of science that is present through the scientific method is also designed in the corridor of rationality and empirical discoveries, while the resulting theory is hypothetical (allegations that require testing). Construction of a theory must be equipped with an empirical approach in testing the truth of the proposed theory. Explanations that have not been empirically tested are only regarded as hypotheses or conjectures. This hypothesis is then tested empirically for truth. Based on the rationality of the ontology and epistemology of science which must and can only be done empirically, then the axiology of science is determined; whether science is useful or not, meets ethical standards or not. The key word is that science is full of interests, both the interests of science itself, the benefit of many people, to power. The intertwined interests of science for science, society and power are the axiological measures of science. The scientific trilogy relation actually has scientific ambiguity, which is usually considered as an important rule of science, which is value-free. Science is claimed to be built epistemically through the scientific method that is free of value, but in fact axiologically science is declared to be constructed and photographed in the spaces of human interests as far as the interests of scientists, society, or power span. 


\subsection{Towards Paradigma Nusantara}

“...Pangeran Moho Loman, Suci, lan Sineja. Mugi kulo sedoyo tiyang beja. Duh Gusti Ingkang Mireng, Mirsani, lan Ngijeni. Nyuwun kulo ing nikmat ingkang tanpo ngitung. Njenengan Lamun Kersa "Wujudo" Nuli Ana. Mboten Wonten Halangan Njenengan Lamun Kersa. Duh Gusti Kang Sugih, Pinuji, lan Ngrejekeni. Nyuwun kulo mung slamet dunia akherat sami. Kelawan Asma Agung tuan mugi hasil sedaya. Sejo sageto eling lan syukur sediokolo..." Syi'ir Gus Mik (KH. Hamim Jazuli)

Syi'ir Gus Mik shows that the expressions and motives of humanity are very closely related to the existence of his/her God. Javanese syi'ir which is the embodiment of the substance of Islamic religiosity from Asma Allah (name of Allah), the Holiness of Allah, the Most Rich, All-Knowing, All-Seeing, and others, are hummed every time with surrender without pause. The Javanese expression of Islam may manifest in the form of Malay-Islamic, Sasak-Islamic, and many localities that are present in the archipelago, but still prioritize the religiosity of Islam itself. The accounting science paradigm typical of the Nusantara needs and can be built through what I call the Kaidah (or tenets), which are not based on a trilogy of modern philosophical assumptions, but science that is unique without being cornered at the localistic level, while civilizations outside the Nusantara that happen to be dominant at this time are an established civilization of culture, science and technology. The term kaidah has also been employed by Islamic Business and Economics Lecturers Forum in devising Prosperous Universe concept [27]. I believe what the Qur'an says that there really is no East or West, because the East and West belongs to Allah. Wherever you turn, there is the face of Allah (Surah 2:115). It is true that life in which science and technology develops does not need an East or West orientation. Everything is just space and time where humans should do original good (Qur'an 2: 177). The important tenet is that religiosity is timeless in the space where science and time exist, if at this time I am part of the Nusantara. This is the main substance of what I name Paradigma Nusantara.

There are several substances that can be the basis for determining the tenets of the Paradigma Nusantara. The main tenet here is not "an assumption" as the modern worldview understands science. Tenets are certainly different from the character of assumptions and form the basis for modern/Western science. Tenets are different from assumptions, because they are based on everything related to the worldview of every human being and society which is always fundamental and becomes the foundation of everything, whether concrete, material, imaginable, as well as abstract to those that cannot be sensed. prophetic, divine and always has the expression of khuluqiyah (morality that is moral in nature as the teachings of the Nusantara's religion and culture) which are integrated in the realm of thought and praxis of humanity. Based on this definition, it can be explained here four kaidah (tenets) for the Nusantara Science Paradigm.

\subsubsection{The first kaidah/tenet: Nusantara Being}

This tenet is a form of rejection to the philosophical assumptions of dominant science as an affirmation of the decolonization of science. The birth of the first phase of colonialism did not stop after the second world war with the emergence of nationalism in countries and with that, every country has independence in the life of the nation and state, 
including how science can be independent according to their ideology and or values. Pancasila as the ideology and world view of Indonesian people cannot automatically be reduced to a scientific world view, if scientists and academics are not aware of the existence of a new, massive form of colonialism. Historical facts show that colonialism has changed from physical violence and explicitly formed a new colonialism. The old colonialism has metamorphosed from the old face which is a mixture of commercial and financial interests, ideology and religion, military power and political intelligence, the cultivation of unimaginable violence and cruelty, which is the hallmark of modern colonialism) with soft power mechanisms becoming increasingly popular, decisive for neocolonial progress in the form of the dominance of knowledge and the reality of everything that is epistemic and philosophically radical. Several key accounting neoliberal scientists and corporate funders have even assisted in the development of positive accounting theory and shareholder value doctrine. They were responsible for spreading neoliberal ideas, significantly influencing the current "scientific" curriculum-which is biased towards techniques based on neoclassical economic research. Accounting practices have become part of the social technology colonial outreach from Euro-American institutions to developing countries [28](see Figure 5).

\section{Figure 5. Postcolinealism in Science}

\begin{tabular}{c|c|c|c|}
\hline \multicolumn{3}{|c|}{$\begin{array}{c}\text { Postcolonialism/Neocolonialism of Science } \\
\text { Orientalisme/ Epistemic Violence/ Ideological Hegemony }\end{array}$} \\
\hline $\begin{array}{c}\text { Scientific } \\
\text { philosophical } \\
\text { assumptions }\end{array}$ & Reality & $\begin{array}{c}\text { Scientific } \\
\text { Methods }\end{array}$ & $\begin{array}{c}\text { Construction } \\
\text { of findings }\end{array}$ \\
\hline $\begin{array}{c}\text { Eniversal } \\
\text { Objective }\end{array}$ & $\begin{array}{c}\text { Contextual } \\
\text { Sociological } \\
\text { Otonomy }\end{array}$ & $\begin{array}{c}\text { Separation of } \\
\text { Social and }\end{array}$ & $\begin{array}{c}\text { Theory } \\
\text { (Science) and } \\
\text { Praxis }\end{array}$ \\
\hline $\begin{array}{c}\text { Natural science } \\
\text { (Technology) }\end{array}$
\end{tabular}

The decolonialist view has been widely practiced such as the model Linda Tuhiwai Smith, Gayatri Chakravorty Spivak, Homi K. Bhabha [29-31]; as well as many others. Indonesia has actually carried out a lot of indigenization agendas by prioritizing the strength of its Nusantara values to carry out decolonization. Such acts of decolonization has been done $b$ by Sunan Bonang, Sunan Kalijogo, Sheikh Siti Jenar, HOS Tjokroaminoto, Soekarno, Ki Hadjar Dewantoro, Pakubiwono IV, Soedjatmoko, Hidayat Nataatmadja, Tjoet Njak Dhien, RMP Sosrokartono, amongst others. All of these Nusantara figures have prominent and main Nusantara characters, and do not deny the values that came later, without having to submit to epistemic power, by first carrying out, with what I usually call the divine purification process (in the language of the Qur'an); is commonly referred to as tazkiyah; both tazkiyah an-nas and tazkiyah ummah). Thus, in fact the tenets of Nusantara being are very distinctive as well as geographically characterized 
for example, it is the range in which the people have culture, language, art, traditions and worldviews rooted in a similar family.

Figure 6. Nusantara's Nista, Madya, Uttama in Kakawin Nagarakrtgama

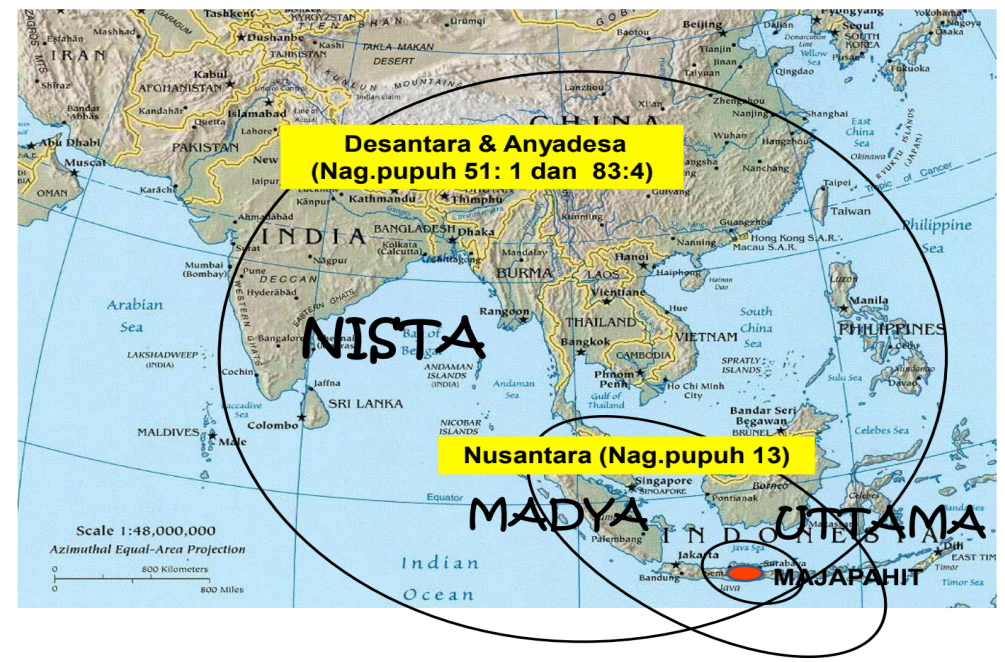

If we use a cultural map that has an Nusantara expression, it can also be referred to as Malay culture, which is currently incorporated in the territory of the Majapahit [32] era in Southeast Asia, such as Indonesia, Malaysia, Brunei Darussalam, Singapore, parts of Thailand and the Philippines, as well as several countries outside Asia. Southeast Asia that has history and closeness, such as Madagascar, Suriname, New Caledonia, Cocos Island, and possibly the Netherlands. The latest and more comprehensive explanation of the term Nusantara or other islands outside of Majapahit refers to the Kakawin Nägarakrtägama Book in pupuh 13-14 that the arrangement of the Majapahit territory is based on the Tri Angga concept, which consists of (1) a nista (shameful) area, outside the core area, (2) madya, the central region as a support, and (3) uttama, the sacred region. Tri Angga itself is a derivative of the conceptual idea of the order of the universe, namely Tri Loka, which consists of the universe Bhurloka/nista, Bhuwarloka/madya, and Swarloka/uttama. Based on the Tri Angga concept, Majapahit positioned the area in East Java as the main area, while outside of that the archipelago and the Malay Peninsula as an intermediate region, while the area called Southeast Asia, India, and China today, is a Mitra Satata area and is called a nista area [33] (see Figure 6-7).

\subsubsection{The second tenet: integral view of reality}

The principle of an integral view of reality emphasizes the unity of understanding and practice of reality which is always intertwined, unified, intact, embedded, and impossible to be separated from one another regarding on how humans perceive reality. Reality is always present in the reality of subjectivity as well as objectivity in which there are the main divine values without pause, anywhere and anytime. Reality is never material or immaterial even non-material, because reality is an ever-living creation and that is why God is present in all life in reality. Reality is always in the substance of divine sanctity 
moving in the trajectory of space and time as well as transcending it and thus science is always alive (the living science).

Figure 7. Tri Angga Region

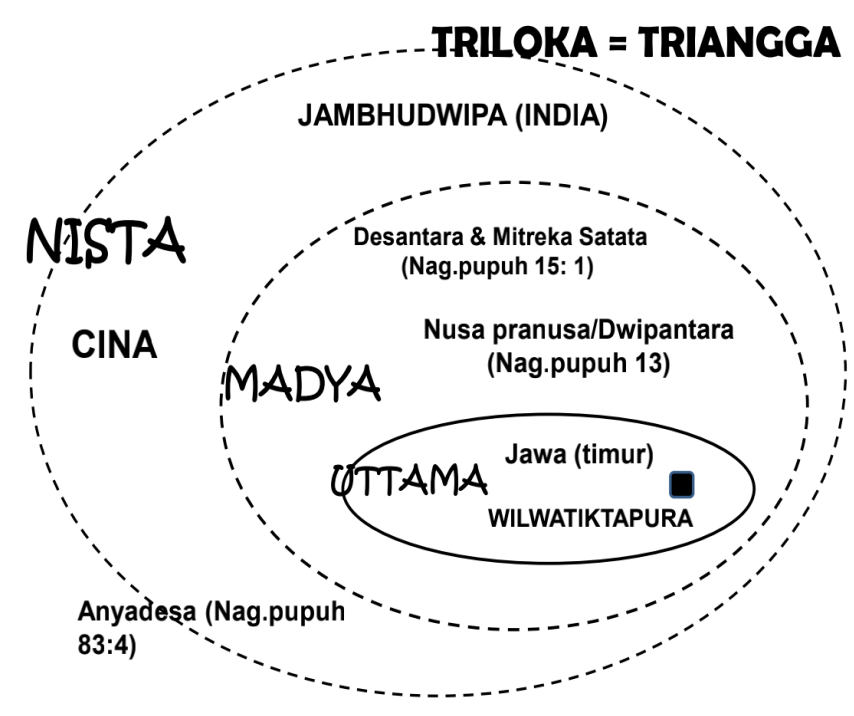

Science is no longer a matter of East and West, because both have entered the trap of the same global reality, the Religion of Machine Man, the religion of soulless humans, humans who have lost their sanctity. The current struggle between the New Silk Road and the West is actually the result of the relationality of the latest civilization and the historicity movement of the power of science, technology, and practice in the sociological space of humanity in the world, all of which revolve around the discourse of acute materialism in the form of economic greed, politics, and all aspects of humanity [34]. The result is clearly visible in the contextuality of the current existing, marginalized God, religion, locality, cultural diversity, into a single logic, material civilization. The sanctity of science in the view of the Nusantara is always holistic, integral, being part of the submission of self and the ummah to the God who created the universe, Allah SWT (human is a servant of God as well as Khalifatullah fil ardh). Science as part of the power of the civilization of the ummah is diametrically different from the secularization logic of Modern science or the religion of the Industrial Revolution as a substitute for traditional religion which calls itself the God of the universe with the ultimate weapon to kill the God of Heaven, namely science and technology. The rejection of the power of science will surely destroy the logic of religious greed. Science through a war that only revolves around the struggle for power over food and energy, including the power of bureaucracy, law and others [35].

Accounting as a branch of science is an important entry point for the legitimacy of material civilization to be returned to its sacred essence. Scientific discourse that emphasizes the main power, namely global financial statements, namely IFRS, and universal accounting ethics, namely ICEPA, both of which are centered on an international institution called IFAC, must be rehabilitated and if necessary delegitimized by prioritizing the main values of religiosity and culture throughout the formulation to practice. The practice of delegitimizing servitude at IFAC is a noble task to free humans from 
misleading the Industrial Revolution 4.0, self-affirmation to restore sacred human nature which has the goal of devotion and love towards the True God through the duties of the people in the world and not being trapped in a wild prison to become Homo Deva (Human Deva) [36] or Homo Deus (Human God)[37].

The loss of sanctity in both the East and the West, at a time when both are fighting on the same logic, materialism and asserting death over the sanctity of science, could be the result of a trade war and political power or it could be part of the failure of humans to control the center of the Machine-Man Religion, namely biotechnology and artificial intelligence. In the end, what we have felt since the end of 2019 and the beginning of 2020 is the Corona Virus Disease 19 (COVID-19) Pandemic which can not be known how long it is going to last. It is true what Karen Armstrong said that it is not religion that has a violent nature, but modernity which is very clearly anti-religion (traditional) [38-41]. Godfree modern science and technology religion is the cause. Restoring purity and prophetic light is the task of a true accountant with a Nusantara spirit by shifting the secular nature or Homo Deus, towards Insan Kamil, who in the deepest mind until the whole horizon stretches out God is the True Ruler, and thus reality is not just a scattering of wealth, money, to material transactions; but all is the reality of holiness, with reference to the prophetic nature (worth the moral power of prophethood).

\subsubsection{The third tenet: religiosity and culture}

Restoring holiness which is an important part of the integral rule of reality can refer to, for example, the da'wah practice of Sunan Kalijaga or commonly called Sunan Kali. One of the members of Wali Songo is known as a creative preacher with his distinctive da'wah methodological work, cultural da'wah (Tut Wuri Angiseni). Sunan Kali carried out cultural da'wah by referring to the sunnah of the Prophet Muhammad PBUH on orders with revelations from God who was guided through the revelation of the holy Quran in Arabic. The Arabic language of the Qur'an as explained and studied by experts is a language that has a high literary content, not the Arabic language used by Arab society at that time. This is because culturally the Arab community in addition to speaking the common Arabic language, also very much adore someone's ability when presenting Arabic poetry literature. The same is true for Sunan Kali, who brought Islam to provide enlightenment for the people in Java by exploring their inner world culturally, for example by listening to kidung (song) and wayang (puppet) [42-44]. Another important thing is that Sunan Kali's cultural da'wah process was carried out as a translation of the results of the trial of the Guardians in the foyer of the Ampek Denta Mosque. The results of the trial were recorded in the minutes of the ulema's deliberation led by Sunan Ampel [45].

Sunan Kali's cultural da'wah practice later formed many works of art and literature typical of Java but were very full of Islamic teachings [46]. For example, the song is famous and is still used by many Javanese people to this day, one of which is the Song of Rumekso Ing Wengi which I present on the first page of this article. There are also other chants, such as Lir-ilir, Gundul-gundul Pacul, Dandanggula. Sunan Kalijaga is indeed known as a scholar as well as a creative artist. It was he who created the taqwa clothes, the art of carving leaf motifs, drums, sekaten gongs [46]. His important works as a form of written teachings are Serat Dewa Ruci [47] and Suluk Linglung [48]. These two important 
works are actually expressions of the meeting between Javanese tradition (Serat Dewa Ruci whose characters adopt the Mahabhrata story, especially the journey of Bima or Bratasena, one of the Five Pandawas seeking Kasampurnan/Perfection) and Islam (Suluk Linglung presents his spiritual journey in search of Knowledge). The truth reaches Insan Kamil through his meeting and learning from Maulana Maghribi, and Prophet Khidir).

Based on Serat Dewa Ruci which was also later narrated in the context of makrifat in Suluk Linglung, it can be used as the basis for restoring sacred accounting as well as its methodological formulation to build the peak of perfection of (accounting) science, through what is called Cakra Manggilingan Accounting Science. The cakra concept is taken from the Javanese view of life who understands life is always in the form of a cycle called the Manggilingan Cakra. The Manggilingan Accounting Science Cakra can thus be constructed based on four levels: Cakra one, the liberation of science from the world's greedy values; Cakra two, liberation of science from the values of self-centeredness; Cakra three, public and universal oriented science practice. The three cakras always rotate in one main point as the main controller called the Tapa Suwung Divine Cakra towards the Supreme Light (see Figure 8). Cakra Manggilingan Accounting Science is a cyclical process that is always present and aims to reach The One that is present.

Figure 8. Cakra Manggilingan Accounting Science

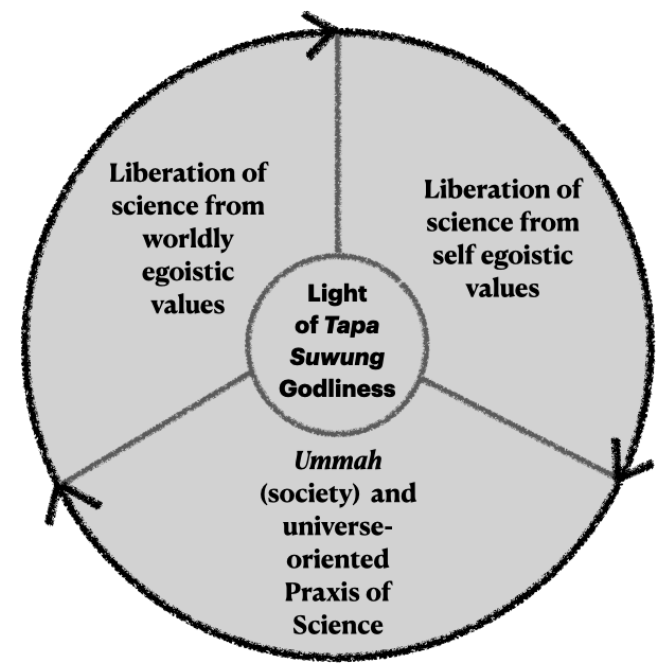

The two main values of religiosity and culture are important references that emphasize that reality is timeless in the space where science and time exist and thus the intertwining of the two will move how science can be translated into existing space and time. Understanding past history, both synchronic and diachronic, is not separated into a reality that is not reality as it is and is material, but as the second tenet which sees that science always lives across time and space, history must have an intuitive and sacred channel that must be captured as ibrah (lesson). At the same time, this is a value that is never broken and continues to be a historical value, which with that, science has the values of virtue that are present. An expression of holiness in which the relation between religiosity and culture can be proven through experience that is always present and forms a distinctive and unique awareness, such as the sacred activities carried out by HOS Tjokroaminoto and RMP 
Sosrokartono are present in the existing space and time and with that the word 'era' becomes important. It has present and future orientation in it and has a purpose. The proof of the sanctity that remains and always lives across space and time which I have presented at an international conference regarding the sanctity of accounting. This sanctity has always been present from the time of Al Khwarizmi, until that holiness was caught by two friends of accounting scientists and artists of the Renaissance in Italy, Luca Pacioli and Leonardo da Vinci. Accounting, mathematics, numbers, art, painting, and anything else that is human work, to me are the same as works in which God never let go of himself, and because of that, holiness is never lost. Holiness is the necessity of history, the necessity of space and time, even passing beyond it, because that is what holiness is actually present, as God is present anywhere, anytime. Al Khwarizmi, Luca Pacioli and Leonardo Da Vinci are just a few humans on the trajectory of history who have proven the Holiness they believe in and have faith upon.

Bringing culture closer to the spaces of human religiosity indeed causes a lot of intellectual attraction. The message of culture as the key word for the success of a country that is independent, truly independent, sovereign and shows its true identity is not easy. Soedjatmoko, a national figure who has a great concern for culture, believes that the ideals of modern Indonesian man can only happen with the synergy of national development through science and technology with the power of culture. Indeed, only promoting science and technology without culture will lead to what Benny Hoedoro Hoed calls Cultural Amnesia or Semiosis Crisis. Cultural amnesia will make people forget and lose the way to understand the meaning of their past history as well as lose the way to understand complexities outside themselves (chaotic semiosis) which has an impact on losing the ability to see the future. If cultural amesia occurs accompanied by crises in many areas of life, then cultural amnesia is actually a symptom of the cultural crisis itself. The way to cure it is to to strengthen the anchorage culture through patron-client contextualization. The technical steps could be preserving history, drawing inspirational threads for the heroic struggle of the founding fathers, and interpreting more in a constructive design the traces of past history that can be used as a framework to restore confidence and national identity. Soedjatmoko called it the Cultural Politics. Cultural Politics must penetrate all aspects of the nation's life, both through systems, values, teaching, and educational activities as well as acceptance of new science and technology. The idea of "Culture with a Religious Spirit" to encourage changes in Soedjatmoko's "New Humanism" is a radical thought for the True Socialist, in portraying and proposing a fundamental change in how Indonesian people will be in the future: "because it is not something that can be made up or ordered. Many things will depend on the grace of God, (God's finger on man's shoulder) [49] in addition to human consciousness." These are the keywords of the tenet of religiosity and culture.

\subsubsection{The fourth tenet: the objective of Paradigma Nusantara}

The goal of Nusantara Science is centered on a belief in life and true goodness rooted in religiosity and justice. The purpose of science as the nature of the Nusantara is always oriented to the main value of holiness towards the True Divinity by prioritizing the integrity of reality according to the second tenet. Achievement of goals is not only rational 
but unites and moves in the purity of inner consciousness in order to achieve the ultimate goal of true humanity, namely common welfare (in Islamic language it is called Khoiru Ummah which is the culmination of the evolution of the Ummatan Wahidah and Ummatan Wasathan public agendas). The fourth tenet does not stand alone above all the tenets. All four tenets have a unified whole and thus the expression of belief, goodness of heart rooted in religiosity and justice is clearly visible in the form of theoretical, research, and empirical findings.

Many empirical findings are typical of the archipelago and are clearly different from the empiricism character of Modern science. Research on the construction of spiritual accountability typical of the Nusantara, where accountability is defined, practiced, and reported is a reflection of the activities of Gus Miek's Teaching, one of the leading Sufism figures among Nahdlatul Ulama'. This accountability is called (spiritual) accountability recitation of the Sema'an Qur'an Recitation of Jantiko Mantab and Dzikrul Ghofilin whose form is accountability for the purity and accountability of services (outward and inner aspects) that form a pyramid of intertwined shari'a, tarekat, essence and makrifat with social and informal dimensions (trust, aspirations, loyalty, and patronage relationships as well as social status which is a proxy for social accountability) [50]. Other research that encourages religious goals in cultural garb, for example, can be done using the Burhani approach (typical Islamic rationality) on the concept of dowry (compulsory gifts from husbands to women to be married) in the context of sharia accounting in Gorontalo [51].

Agricultural accounting research also gives a signal about the goal of holistic welfare according to the principles of the archipelago. Farmers, for example, do not prioritize material aspects in expressing their biological assets. Money, profit, harvest, and accounting activities in agriculture for farmers are not the only way that is put forward in understanding the meaning of happiness and prosperity. For farmers, the measurement of biological assets is not only monetary; for them is the sum total of various economic and non-economic utilities. The motives underlying the understanding of farmers are very complex, ranging from religious, cultural, to sociological ones. The complex relation between religion, culture and social sociology can be seen for example from religious activities that have strong local cultural expressions such as pre-planting rituals, offerings, village parties (kenduri), harvesting, to post-harvest salvation in many villages in many areas with the terms and various practices. Economic motives are not what we imagine in conventional economic theories which are based on individual transactions and profit maximization. Social expression and togetherness are very visible. Many findings legitimize such as Rizaldy (2012), Wahyuni (2013), Niswatin and Mahdalena (2016), Ardani et. al. (2016), and Hariadi et. al. (2016), Kurniawan et. al. (2016), Wahyuningsih (2011), Elanda et. al (2012), Khasanah (2013) Harkaneri (2013), and Izzah (2018) [7].

An example of writing that has the strength of the integrity of the four rules in order to achieve the goal of the fourth rule regarding the construction of a methodology using the thoughts and struggles of Tjoet Njak Dhien [52]. Tjoet Njak Dhien was a great figure from Aceh during the struggle to free himself from colonialism and occupation that destroyed almost all of the country's resources. The methodological construction presented is an antithesis to the use of the feminism paradigm which will inevitably create a bias in portraying reality as well as building a methodology for accounting. Another example 
which has enough paradigmatic power for the four principles of the Nusantara Paradigm to later give rise to a unique methodological formula for the archipelago is the article entitled Gayatri: Accountants of Majapahit [6]. Based on historical tracing in the heyday of Majapahit where the concept of Accounting Power in the style of Gayatri, it is not like seeing historical power in the style of Foucauldian, but the power of accountants always puts forward the power of justice which is full of religiosity.

\section{Conclusion}

The main rule of the Paradigma Nusantara is the establishment of how later science can be formed through its methodological framework. The use of Nusantara perspective gives us space to be creative in the corridors of thoughts and philosophies that are still present in society, in this case our Nusantara. Efforts to redirect the nature of science (accounting) and humans (accountants) to the true nature; science that is alive with the divine spirit and not mortal science in space and time; needs to be achieved through awareness, that God is the center of the existence of everything, both in the East as well as in the West. The Paradigma Nusantara is neither in the East nor the West. The Paradigma Nusantara is a paradigm that reflects the universe itself, as the Qur'an asserts that East and West belong to Allah, not humans. Nusantara Science is thus not an objective-subjective problem, separating the world and the hereafter (world religion and praxis), nor is it epistemologically trapped in the battle of paradigms of positivism and non-positivism, let alone only driving the two major camps of Eastern science vis a vis West. True Nusantara Science is a vision of achieving truth with a true good spirit, which in Islam is called the concept of piety. True goodness as a representation of the Nusantara true science is not the opposition of East or West, but every living and whole science, The Living Science. Nusantara Science (including accounting) is thus a science that always lives in the trajectory of space and time, a period without time, passed by unconditional surrender, sincerity, that is true emptiness towards the unity of holiness, as RMP Sosrokartono wrote: "Trimah mawi pasrah. Suwung pamrih, tebih ajrih; Langgeng, tan ana susah, tan ana seneng. Anteng mantheng, sugeng jeneng ". Nusantara science is an agenda to restore the sacred role of true humanity to Insan Kamil or Nasr (1989) as Pontifical Man [53], wherever they are, in the span of God's universe .

\section{Lir ilir lir ilir tandure wong sumilir}

Tak ijo royo royo

Tak sengguh panganten anyar

Cah angon cah angon penekno blimbing kuwi

Lunyu lunyu penekno kanggo mbasuh dodotiro

Dodotiro dodotiro kumintir bedah ing pinggir

Dondomana jrumatane kanggo seba mengko sore

Mumpung padang rembulane

Mumpung jembar kalangane

Sun suroko surok hiyo

(From the song “Lir-Ilir” by Sunan Kalijogo) 


\section{References:}

[1] Kamayanti A, Ahmar N. Tracing Accounting in Javanese Tradition. Int J Relig Cult Stud 2019;1:15-24. doi:10.34199/ijracs.2019.4.003.

[2] Mulawarman AD. Menyibak Akuntansi Syariah. Yogyakarta: Kreasi Wacana; 2006.

[3] Mulawarman AD. Akuntansi Syariah: Teori, Konsep dan Laporan Keuangan. Jakarta: E-Publishing; 2009.

[4] Kamayanti A. Metodologi Konstruktif Riset Akuntansi: Membumikan Religiositas. Jakarta: Yayasan Rumah Peneleh; 2017.

[5] Aji Dedi Mulawarman, Djuharni D, Setiawan AR, Susanto YK, Mardian S, Baehaqi A, et al. Menulis Artikel Berkualitas: Perspektif Editor. Malang: Penerbit Peneleh; 2021.

[6] Lutfillah NQ. Gayatri: Akuntan Majapahit. Malang: Penerbit Peneleh; 2021.

[7] Mulawarman AD. Akuntansi Pertanian: A Prophetic Legacy. Jakaera: Yayasan Rumah Peneleh; 2019.

[8] Mulawarman AD. Akuntansi Syariah: Teori, Konsep dan Laporan Keuangan. Jakarta: E Publishing Company; 2008.

[9] Triyuwono I. Akuntansi Syariah: Perspektif, Metodologi, dan Teori. Third. Jakarta: PT. Raja Grafindo Persada; 2012.

[10] Sawarjuwono T. Accounting language change: a critical study of Habermas's theory of communicative action. University of Wollongong, 1995.

[11] Rasyid ER. Researching Management Accounting-in-Action: lnterpretive Anthropology as a Methodological Discretion. Int J Account Bus Soc 1994;2.

[12] Sukoharsono EG. Accounting in a 'new'history: a disciplinary power and knowledge of accounting. Int J Account Bus Soc 1994;6:48-79.

[13] Said E. Orientalism. New York Times 2003:1-234.

[14] Hanafi H. From Orientalism to Occidentalism. In: Henriksson K, Kynsilehto A, editors. Build. Peace through Intercult. Dialogue. 2nd ed., Finland: Institut de Recherche de la Paix à Tampere TAPRI; 2008, p. 257-66.

[15] Morris RC, editor. Can the Subaltern Speak?: Reflections on the History of an Idea. Columbia University Press; 2010.

[16] Nataatmadja H. Pemikiran ke Arah Ekonomi Humanistik: Suatu Pengantar menuju Citra Ekonomi Agamawi. Jakarta: Penerbit PLP2M; 1984.

[17] Mulawarman. AD. Akuntansi "Tjokro-an" Kritis ala HOS Tjokroaminoto. Ekon J Paradig Islam Di Bid Ekon Keuangan, Dan Pembang 2014;2:24-37.

[18] Mulawarman AD. Jang Oetama: Jejak dan Perjuangan HOS Tjokroaminoto. Yogyakarta: Galang Press; 2015.

[19] Burrell G, Morgan G. Sociological Paradigms and Organisational Analysis: Elements of the Sociology of Corporate Life. Great Britain: Arena; 1979.

[20] Chua WF. Radical Developments in Accounting Thought. Account Rev 1986;61:601-32.

[21] Mulawarman. AD. Integrasi Paradigma Akuntansi: Refleksi atas Pendekatan Sosiologi dalam Ilmu Akuntansi. J Akunt Multiparadigma 2010;1:155-71.

[22] Brooke-Marciniak BA. Beth A. Brooke-Marciniak n.d. https://www.ey.com/en_ru/people/beth-brooke-marciniak (accessed July 6, 2021).

[23] Rumens N. Sexualities and accounting: A queer theory perspective. Crit Perspect Account 2016;35:111-20. doi:https://doi.org/10.1016/j.cpa.2015.05.003.

[24] Edgley C, Sharma N, Anderson-Gough F. Diversity and professionalism in the Big Four firms: Expectation, celebration and weapon in the battle for talent. Crit Perspect Account 2016;35:13-34. doi:https://doi.org/10.1016/j.cpa.2015.05.005. 
[25] Nisbet RE. The Geography of Thought: How Asians and Westerns Think Differently... and Why. New York: Free Press; 2003.

[26] Indriantoro N, Supomo B. Metode Penelitian Bisnis (Untuk Akuntansi dan Manajemen). Yogyakarta: BPFE; 2009.

[27] FORDEBI T. Kesejahteraan Semesta. Jakarta: Yayasan Rumah Peneleh; 2018.

[28] Ayres RM, Silva CM da, Lourenco RL. Decolonial studies in accounting? Emerging contributions from Latin America. Crit Perspect Account n.d. doi:https://doi.org/10.1016/j.cpa.2020.102281.

[29] Smith. LT. Decolonizing Methodologies: Research and Indigenous Peoples. London: Zed Books; 1999.

[30] Mbembe A. Decolonizing Knowledge and the Question of the Archive. Africa is a Country; 2015.

[31] Said E. Orientalism. London, UK.: Penguin Books; 1977.

[32] Bentley JH, Bridenthal R, Wigen KE, editors. Seascapes: Maritime Histories, Littoral Cultures, and Transoceanic Exchanges. Honolulu: University of Hawai'i Press,; 2007.

[33] Munandar AA. Majapahit dan Negeri-negeri Sezaman: Interaksi dan Pandangan. Berk Arkeol 2020;40:1-24.

[34] Mulawarman AD. The Living Accounting Science. Int. Conf. Relig. Cult. Stud., 2020.

[35] Mulawarman AD. Akuntansi Pertanian: A prophetic legacy. Yayasan Rumah Peneleh. Seri Media dan Literasi; 2019.

[36] Belknap M. Homo Deva: Evolution's Next Step. Lifethread Institute; 2004.

[37] Harari YN. Homo Deus: a Brief History of Tomorrow. Harvill Secker; 2015.

[38] Armstrong K. Fields of Blood: Mengurai Sejarah Hubungan Agama dan Kekerasan. Bandung: Penerbit Mizan; 2011.

[39] Chomsky N. Pirates and Emperor. London: Pluto Press; 2016.

[40] Chomsky N. Who Rules the World. Yogyakarta: Bentang; 2017.

[41] Fuller GE. A World Without Islam. Washingtonpost Newsweek Interactive, LLC 2008:46-53.

[42] Sunyoto A. Atlas Wali Songo: Buku Pertama yang Mengungkap Wali Songo sebagai Fakta Sejarah. Depok: Pustaka Iman; 2012.

[43] Chodjim A. Mistik dan Makrifat Sunan Kalijaga. Jakarta: Serambi; 2003.

[44] Ajidarma S. Sembilan Wali \& Siti Jenar. Penerbit PT. Intisari Mediatama kerjasama and PT. HM. Sampoerna TBK; 2008.

[45] Darban AA. Fragmenta Sejarah Islam Indonesia. Surabaya: Penerbit JP Books; 2008.

[46] Wildan D. Sunan Gunung Jati: Petuah, Pengaruh dan Jejak-jejak Sang Wali di Tanah Jawa karangan. Ciputat: Penerbit Buku Salima Network; 2012.

[47] Shashangka D. Serat Dewa Ruci: Sastrajendrahayuningrat Pangruwating Diyu. Yogyakarta: Penerbit Narasi; 2019.

[48] Zarkasi F. Suluk Linglung Sunan Kalijaga: Pelajaran Terdalam dari Tipe Islam Jawa dan Misteri Nanbi Khidir AS. Bandung: Penerbit Manggu; 2020.

[49] Soedjatmoko. Asia di Mata Soedjatmoko. Kompas 2010.

[50] Prasetio JE. Akuntabilitas Semaan Al Qur'an dan Dzikrul Ghofilin. Malang: Penerbit Peneleh; 2020.

[51] Rahman Y, Naholo S, Santoso IR. Konsep Akuntansi Syariah pada Budaya Mahar. J Akunt Multiparadigma 2019;10. doi:http://dx.doi.org/10.18202/jamal.2019.04.10005. 
[52] Kamayanti A. Riset Akuntansi Kritis: Pendekatan (Non) Feminisme Tjoet Njak Dhien. J Akunt Multiparadigma 2013;4:361-75.

[53] Nasr S. Knowledge and the Sacred. Sunny Press; 1989. 